\title{
2019 APSA Council and Officer Nominees
}

T he APSA Nominating Committee met in January 2019, and has nominated the following candidates for APSA council positions. Each has agreed to serve if elected. The candidates, along with any additional nominations by petition, will be put to a vote by the full membership via electronic ballot in July.

The 2018-19 nominating committee consists of chair Todd Shaw, University of South Carolina; Scott Gehlbach, University of Wisconsin, Madison; Alfred Montero, Carleton College; Alan Jacobs, University of British Columbia; Courtney Jung, University of Toronto; and Janelle Wong, University of Maryland.

\section{PRESIDENT-ELECT (2019-2020)}

\section{Janet Box-Steffensmeier, Ohio State University}

Janet Box-Steffensmeier is Vernal Riffe Professor of Political Science, professor of sociology by courtesy,interim executive dean and vice provost for the College of Arts and Sciences, and lead dean for the Translational Data Analytics Institute at Ohio

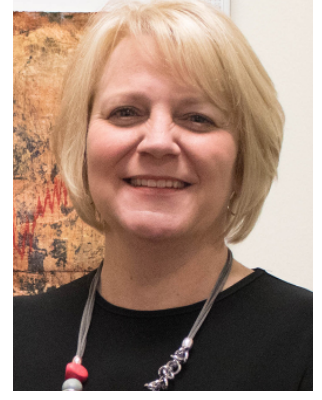
State University (BA, Coe College 1988; $\mathrm{PhD}$, Texas 1993). She formerly served as the faculty representative to the Ohio State Board of Trustees and as divisional dean for Social and Behavioral Sciences. Box-Steffensmeier has served as vice president and treasurer of APSA as well as president of MPSA and the Society for Political Methodology. She is a fellow of the American Academy of Arts and Sciences and an inaugural fellow of the Society for Political Methodology. The Box-Steffensmeier Graduate Student Award, given annually by ICPSR, is in recognition of her contributions and support of women in political methodology. She has received both distinguished mentoring and teaching awards, including the Warren Miller Award for Meritorious Service to the Social Sciences from ICPSR and Outstanding Professional Achievement for Scholarship and Mentorship Award from the MPSA Women's Caucus. Her scholarship uses the lens of both institutions and culture. She also works in the areas of event history, time series and network methodologies.

Statement of Views: APSA is the preeminent body for advancing the profession and engaging in the myriad issues facing higher education, the nation, and the world. The study of political science has immense collective value for understanding and addressing the major issues of our time and those of an enduring nature. It is vital that our members and their work are supported and celebrated as they strive to understand and solve complex problems while communicating potential solutions to peers, decision makers, and the public. It is our collective advantage to do so as a discipline that embraces pluralistic methodologies. APSA is uniquely positioned to make an impact by embracing, welcoming, and more deeply engaging political scientists from a variety of backgrounds who are pursuing academic, industry, and public service careers and fostering those relationships for the benefit of all in our research, teaching, and service. As the leading organization for the study of political science, it is critically important to foster both community and the diversity of ideas as well as personal diversity in our profession.

\section{VICE PRESIDENTS (2010-2020) Kerstin Hamann, University of Central Florida}

Kerstin Hamann is a Pegasus Professor in the Department of Political Science at the University of Central Florida, where she currently serves as department chair. Hamann studies West European politics, especially the role of organized labor in politics, and Spanish politics. Her books include The Politics of Industrial Relations: Labor Unions in Spain; Parties, Elections, and Policy Reforms in Western Europe: Voting for Social Pacts (with John Kelly); and Democracy and Institutional Development: Spain in Comparative Institutional Development (co-edited with Bonnie M. Field). She has also published her research in journals such as Comparative Political Studies, Comparative Politics, British Journal of Industrial Relations, and European Journal of Industrial Relations. Hamann has also published extensively in the field of Scholarship of Teaching and Learning, including Assessment in Political Science (coedited with John Ishiyama and Michelle Deardorff) and she has served as editor in chief of the Journal of Political Science Education.
Hamann is a recipient of the Lifetime Achievement Award by the APSA

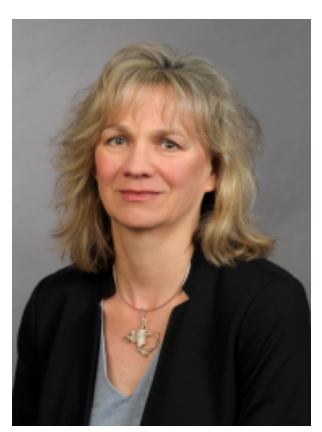

Section on Political Science Education. Her service to APSA includes serving as vice president; member of the $A P S R$ editorial board; chair of the Committee on Teaching and Learning; cofounder of the Distinguished Teaching Award; vice chair, Political Science Education Section; cofounder of the Iberian Politics Related Group; and member of the Committee on Governance Reform, among others. Currently she serves as treasurer of the SPSA and as a member of the SPSA Finance Committee. Her service to professional associations also includes serving on the national board of Pi Sigma Alpha, among others.

At UCF, Hamann is a recipient of numerous awards, including the UCF Excellence in Undergraduate Teaching Award and the UCF Excellence in Professional Service Award as well as Research Incentive Awards and university-wide Scholarship of Teaching and Learning Awards.

Statement of Views: Political scientists work across a variety of academic institutions, ranks, and responsibilities. The institutions we work in include two-year institutions, four-colleges, comprehensive institutions, MA granting institutions, and PhD granting universities; our academic ranks range from graduate students and contingent faculty to endowed professors; some spend most of their time with teaching, while others' primary responsibility lies in the research area. Together, we form the community of political scientists. I believe that it is important for the association to constitute a home for all political scientists and to represent and provide services for the diversity of academics in the discipline regardless of institution, rank, and primary responsibilities. In addition, political scientists make important contributions as members of think tanks, non-profit organizations, and the policy community. If elected, I will support APSA's continued efforts to support pluralism and diversity in the discipline across ranks and institutions, 
and also including those in non-academic positions.

\section{Leonard Wantchekon, Princeton University}

Leonard Wantchekon is professor of politics, international affairs and econom-

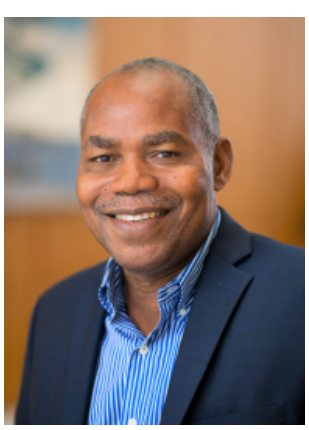

ics (associate faculty) at Princeton University. He previously was a faculty member at New York University and Yale University and holds a $\mathrm{PhD}$ in Economics from North-

western University.

Wantchekon's research centers on political and economic development in Africa, focusing on human capital investment, democratization, clientelism and redistributive politics, the resource curse, and the long-term social impact of slavery. He has written numerous articles for leading academic journals including the American Economic Review, American Political Science Review, American Journal of Political Science, and the Quarterly Journal of Economics and World Politics.

His scholarship is shaped in part by his experiences as a left-wing pro-democracy student activist under a repressive military regime in his native Benin from 1976 to 1987. He reflects on this experience in his auto-biography "Rever-a-Contre Courant" (Dreaming Against the Current), Harmattan (2012).

Wantchekon is a member of the American Academy of Arts and Sciences, a fellow of the Econometric Society. He served as secretary of APSA and on the executive committee of the Afrobarometer Network. Finally, he is the founder and president of the African School of Economics which opened in Benin in 2014.

Statement of Views: As vice president of APSA, I will work at strengthening the position of the association as a leading global institution, contributing to the emergence of new and world class research and training programs not only in North America and Europe, but also Africa, Asia, Latin America and the Middle East. In addition, I strongly believe that APSA should promote active collaboration between subfields in political science and across social science disciplines. For example, the association should create platforms where political theorists join forces with political economists to rethink, say, deliberative democracy or where comparativists would work with American politics scholars to develop novel approaches to study clientelism, redistributive and identity politics. Finally, in my view, the association should particularly work at promoting diversity and inclusion in graduate admission and faculty recruitment. It could, for instance, sponsor rigorous and large-scale studies on the status of minority groups and women in the profession and/or contribute to the creation of robust pipelines for students from minority groups to enter graduate programs and academia.

My commitment to these goals is illustrated by professional experience highlighted in my bio, particularity the creation and development of the African School of Economics.

\section{Melissa Williams, University of Toronto}

Melissa S. Williams is professor of political science at the University of Toronto. Her work has been concentrated in contemporary democratic theory with a focus on

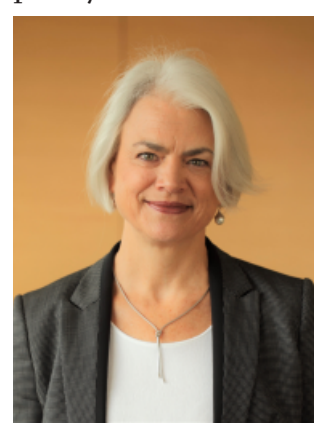
the meaning of political equality under circumstances of structural inequality. In recent years, Williams has turned toward the implications of globalization for democratic theory and has fostered new work in comparative political theory.

Williams was founding director of the Centre for Ethics at the University of Toronto, and has held visiting fellowships at the Ash Center for Democratic Governance and Innovation at the Harvard Kennedy School, the Justitia Amplificata program at Goethe University and the Free University, the Center for Human Values at Princeton University, the University of Amsterdam, and the Safra Center for Ethics at Harvard University. She has served as editor of NOMOS; team leader of the international research project, East Asian Perspectives on Politics; and a member of the advisory board of Critical Review of International Social and Political Philosophy. She has also served on two APSA President's Task Forces and as a member of council. Williams is author of the award-winning
Voice, Trust, and Memory: Marginalized Groups and the Failings of Liberal Representation (Princeton, 1998), and has published articles in numerous journals and edited collections. She has also edited or coedited 11 volumes, including Jane J. Mansbridge: Participation, Deliberation and Legitimate Coercion (Routledge, 2018), East Asian Perspectives on Political Legitimacy: Bridging the Empirical-Normative Divide (Cambridge, 2016), and De-Parochializing Political Theory (Cambridge, forthcoming).

Statement of Views: Diversity. Pluralism. These two terms-the one in reference to demographics, the other, to methodology and methods-lie at the heart of my concerns. Should I be elected vice president, I will work to sustain and expand the efforts of previous APSA leadership to ensure that diversity, in all its aspects, and methodological pluralism continue to permeate the discipline and the association, and even to grow in spaces where they have not flourished. Many in the US and around the world are currently immersed in reflecting on the challenges facing us all. I would like to see the professional association of political scientists be similarly selfreflective-and proactive.

\section{COUNCIL (2019-2022)}

\section{Ben Ansell, University of Oxford}

Ben Ansell received his $\mathrm{PhD}$ in Government from Harvard University in 2006. $\mathrm{He}$ is professor of comparative democratic institutions at Nuffield College and the

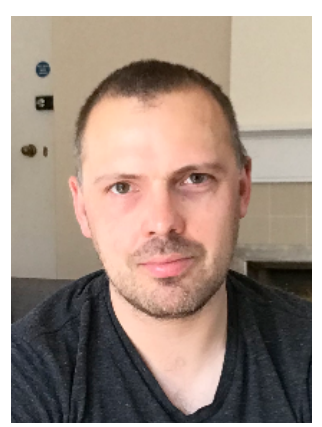

University of Oxford and was previously associate professor of political science at the University of Minnesota. $\mathrm{He}$ is currently coeditor of Comparative Political Studies and the principal investigator of the European Research Council project WEALTHPOL: The Politics of Wealth Inequality. His work spans a wide array of topics in political economy, from the politics of education, to inequality and democratization, to more recent work on housing, wealth, and populism. His first book From the Ballot to the Blackboard: The Redistributive Political Economy of Education (Cambridge University Press, 2010) won the William H. Riker award for best book in political economy and his second book, coauthored with 
David Samuels, Inequality and Democratization: An Elite-Competition Approach won the Riker award and the Woodrow Wilson award for best book in political science in 2014. He has published in many journals, including International Organization, World Politics, Comparative Political Studies, and the American Political Science Review. He is currently a member of the Max Planck Scientific Advisory Board and was made fellow of the British Academy in 2018.

Statement of Views: I strongly believe in encouraging the breadth of intellectual work in political science and in its leading journals and my time on APSA Council, if elected, would be devoted to that end. As a scholar based in Europe, I am also keen for APSA to continue to serve as a hub for international political science, including especially less well-resourced countries and regions. As one of the editors of Comparative Political Studies, I hope to bring some of that experience to APSA's stable of journals.

\section{Erik Bleich, Middlebury College}

Erik Bleich received his $\mathrm{PhD}$ in political science from Harvard University in 1999 and is Charles A. Dana Professor of Political Science and chair of the Department of

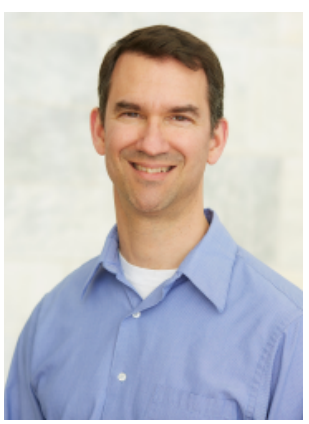
Political Science at Middlebury College. His scholarship focuses on race and ethnic politics in Europe and North America, and on the role of ideas in politics. He is the author of The Freedom to Be Racist? How the United States and Europe Struggle to Preserve Freedom and Combat Racism (Oxford University Press, 2011) and Race Politics in Britain and France: Ideas and Policymaking since the 196os (Cambridge University Press, 2003), as well as the editor or coeditor of three collections of essays. He has published articles in journals such as Comparative Politics, Comparative Political Studies, and World Politics. He has also contributed to public discussions in AlJazeera English, the Atlantic, the Financial Times, the Guardian, and the Washington Post/Monkey Cage. He teaches survey courses on comparative politics and European politics, as well as courses on free speech versus racist speech in the United States and Europe, and the politics of diversity in Europe. He is the director of the Media Portrayals of Minorities
Project, which uses computer-assisted techniques to analyze tens of thousands of newspaper articles about particular groups. $\mathrm{He}$ is currently working on a coauthored book about media portrayals of Muslims in comparative perspective. Bleich is the 2019-2021 chair of the Executive Committee of the Council for European Studies.

Statement of Views: I would be honored to be part of the APSA Council. I have been able to serve the discipline as a member of the Steering Committee of the two-year long Qualitative Transparency Deliberations and was co-chair for the Advanced Industrialized States section selection process for the 2016 APSA Annual Meeting. Based on my experience as a faculty member of a liberal arts college, I would bring a perspective that focuses equally on our roles as scholars and teachers of political science. As someone who uses both qualitative and quantitative techniques, and who has coauthored and published across the disciplinary boundaries as well as with undergraduate students, I believe I could serve as a bridge builder linking multiple groups. I would strive to include all perspectives in our collective governance.

\section{Alexandra Filindra, University of Illinois at Chicago}

Alexandra Filindra is associate professor of political science at the University of Illinois, Chicago. She specializes in American immigration policy, racial prejudice and its effects on policy preferences, public opinion, and political psychology. Dr. Filindra received her PhD from Rutgers University

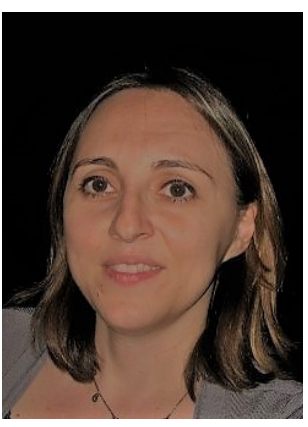

and served as a post-doctoral researcher at Brown University's Taubman Center for Public Policy and American Institutions and the Center for the Study of Human Development. Her work has appeared in Political Behavior, Policy Studies Journal, State Politics and Policy Quarterly, Social Science Quarterly, Urban Affairs Review, Harvard Education Review, Migration Studies, International Migration and other scholarly journals. Her research has been supported by grants from the University of Illinois at Chicago, the Pew Center for the States, the Russell Sage Foundation, the Bill and Melinda Gates Foundation, and the Rhode
Island Foundation. She is the recipient of three best paper awards from APSA and the Lucius Barker Award from MPSA.

Statement of Views: As a newly minted journal editor, I cannot help but notice the difference in quality of paper submissions between graduate students and many junior scholars, especially those submitting solo work, and more experienced faculty authors, as well as within junior scholars from different types of institutions. From reading these papers, it is clear to me that what most people who are entering the job market (or who are in their first job) don't lack in good ideas but have not had rather sufficient mentorship and support that would allow them to develop the proper skills required for publishing articles. Because of rejections, many younger scholars may get discouraged and withdraw from publishing or the profession altogether. This is likely to exacerbate gender and race biases already existent in the profession. If elected, I would like to work with the board and the APSA journals to address this problem. I would like to start a discussion of how to better support the new generation of scholars while respecting the standards and editorial discretion afforded to journals.

\section{Rebecca Gill, University of Nevada, Las Vegas}

Rebecca Gill is the director of the Women's Research Institute of Nevada and associate professor of political science at the University of Nevada, Las Vegas. Her recent research focuses on gender, politics, and

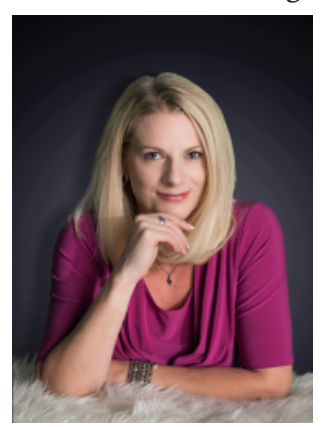
courts. She is the recipient of a National Science Found a tion grant to study gender and race bias in performance evaluations of state judges. Her work on judges and judicial institutions focuses on courts in the United States and Australia. Gender and intersectional equity in academia is also an important part of Gill's current work. She is currently collaborating with scholars from across the discipline to combat harassment and work toward a more diverse, inclusive academic environment in political science and beyond.

Gill is the coauthor of Judicialization of Politics: The Interplay of Institutional Structure, Legal Doctrine, and Politics on the High 
Court of Australia (Carolina Academic Press, 2012). Her work has appeared in scholarly outlets including Law \& Society Review; State Politics \& Policy Quarterly; Journal of Women, Politics, and Policy; Politics, Groups, and Identities; the Ohio State Law Journal; and the Georgetown Law Journal. Her work has been featured in a number of popular outlets, like the Washington Post, the Las Vegas Review-Journal, and the Wall Street Journal Law Blog.

Statement of Views: It is an honor to be nominated to serve on the APSA Council. I believe that a welcoming discipline achieves diversity and inclusion in part through the cultivation of norms of professionalism and respect. These goals can be realized by professional associations that actively encourage the development of a sense of shared purpose among members. If elected, I will support APSA's ongoing efforts to encourage broad-based participation and the equitable distribution of power and resources in the discipline. I am particularly interested in fostering pathways and processes that increase accessibility for traditionally underrepresented scholars, including parents and caregivers and those working across academic roles. For me, this work requires a commitment to scholarship evaluating how hierarchies are maintained and how institutions can be reformed to eliminate structural inequities that hinder individuals from fulfilling their potentials. It is important to me that we extend these discussions beyond the boundaries of our discipline to engage our departments, our colleges and universities, and our communities. I believe that APSA and its members have a duty to participate thoughtfully in broader discussions about intellectualism and inclusiveness in public life.

\section{Soo Yeon Kim, National University of Singapore}

Soo Yeon Kim is associate professor and head of the Department of Political Science at the National University of Singapore. She is a former fellow of the Transatlantic Academy, based at the German Marshall Fund of the United States (Washington, DC), and of the Niehaus Center for Globalization and Governance, Woodrow Wilson School of Public and International Affairs, Princeton University. Soo Yeon Kim holds a $\mathrm{PhD}$ in political science from Yale University and BA in political science and international relations from Yonsei University. Her current research focuses on production networks, multinational firms, and the politics of free trade agreements in Asia; the politics of compliance in WTO disputes; and rising powers in the global economy. Soo Yeon Kim's recent publications include "Global Value Chains and the Political

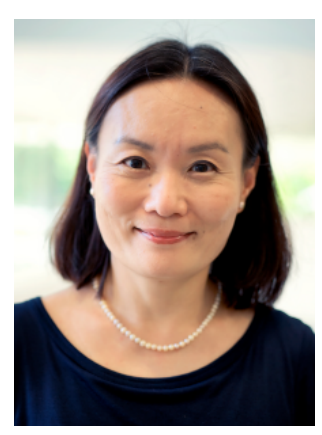

Economy of WTO Disputes," (with Gabriele Spilker), 2019, Review of International Organizations; "The Regime Complex for Investment Governance: Overlapping Provisions in PTAs and BITs" (with Clara Lee), in Manfred Elsig, Michael Hahn, and Gabriele Spilker, eds., The Shifting Landscape of Global Trade Governance (Cambridge University Press, forthcoming); and and "Yin and Yank: Public Opinion in Europe Toward the United States and China" (with Sophie Meunier and Zsolt Nyiri), 2016, Comparative European Politics.

Statement of Views: I am a US-trained political scientist based in Asia. In the eight years that I have been at the National University of Singapore, I have maintained my visibility in the field and have been a regular participant at APSA meetings. I have also developed strong networks that link Singapore with other institutions of higher learning in East Asia, Southeast Asia, and the United States. I am committed to the internationalization of political science, contributing to the growth of an international, regionally diverse community of scholars whose research engages the important debates of our times. In 2018, I joined the APSA Asia Workshop Committee and its efforts to reach out to political science scholars studying and working in Asia and on Asia. We will be holding our first Asia Workshop in Penang in June 2019. I very much share the vision of the APSA Asia Workshop Committee to ensure that the community of political scientists outside the United States is represented and wellintegrated into the discipline. If elected to the APSA Council, my main contribution would be in this same direction, to increase awareness of Asia and its scholarly community within APSA and to assist in expanding APSA's international outreach activities.

\section{David L. Leal, University of Texas, Austin}

David L. Leal is professor of government and director of the Immigration Studies
Initiative at the University of Texas at Austin. His primary academic interest is Latino politics, and his work explores questions involving public policy, political behavior, and public opinion. He has published four dozen articles in political science and interdisciplinary journals and is the coeditor of nine volumes on Latino politics and immigration policy. He has served as co-chair of the APSA Committee

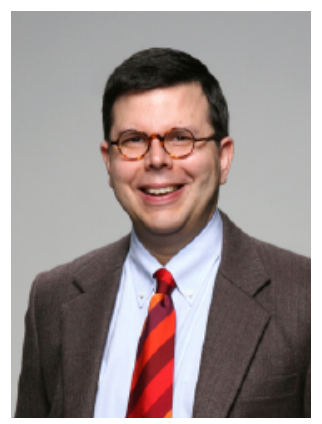

on the Status of Latinos y Latinas in the Profession (2004-06) and in 2017 received its Adaljiza SosaRiddell Award for Exemplary Mentoring of Undergraduate Latino/a Students. He was a member of the APSA Task Force on Religion and American Democracy from 2006-2008 and an APSA Congressional Fellow from 1998-99. He is currently an associate member of Nuffield College (University of Oxford) and a senior fellow at the Hoover Institution (Stanford University), and he was a Fulbright Distinguished Lecturer in Japan in July of 2014. He received his PhD in political science from Harvard University in 1998 and was named a Distinguished Alumni Scholar by Stanford University in 2013.

Statement of Views: We live in a time when higher education in general, and political science in particular, face significant questions and criticisms. Is political science a "real" discipline? Should the federal government fund social science research? Should students major in something more "practical"?

While this environment can be challenging, it is also an opportunity to demonstrate the value of the social scientific study of politics to our many stakeholders. With a foundation of methodological and substantive pluralism, our discipline is well positioned to bring a wide variety of useful perspectives to bear on contemporary politics and policy. We have a persuasive case to make about the unique value of political science for educating students, enriching public debates, and enhancing democracy-but we must vigorously make it. As a council member, I will encourage APSA efforts to explain our educational and research contributions and to work jointly with other social science associations to 
advance our common interests. More than ever, we need to reach the students, parents, taxpayers, donors, voters, politicians, and trustees whose support is essential to the advancement of the modern university and the social science disciplines.

\section{Suzanna Linn, Pennsylvania State University}

Suzanna Linn is liberal arts professor of political science at Penn State University and member of the graduate faculty in Social Data Analytics. She received her PhD from the University of Iowa in 1994. She is a Fellow and president-elect of the Society for Political Methodology. Professor Linn

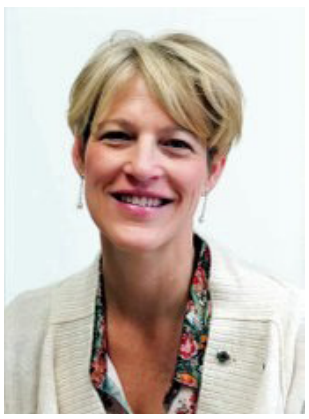
has endeavored to develop methods that facilitate applied time series analysis. Recently her interest has focused on identifying the consequences of decisions analysts face when conducting text analysis and explicating strategies for making good choices. Her substantive research seeks to better understand the dynamics of American public opinion and election outcomes, particularly in the context of the increasingly disparate economic conditions, health outcomes and opportunities facing Americans. Her work has appeared in a number of journals including the American Political Science Review, American Journal of Political Science, Political Analysis, Statistics in Medicine, and the Journal of Politics. Her book The Decline of the Death Penalty and the Discovery of Innocence with Frank Baumgartner and Amber Boydstun was awarded the Gladys M. Kammerer Award by APSA for the best book on US national policy in 2008.

Professor Linn has contributed to the discipline in many capacities. She has served as a member of the executive council of MPSA and the council of the APSA Political Forecasting Group and has worked on numerous committees within both the APSA and MPSA. She has twice been associate editor of Political Analysis and has been on numerous editorial boards as well as NSF advisory panels in Methodology, Measurement, and Statistics, EITM, and Political Science. She has worked to promote diversity within political methodology and is an officer in Visions in
Methodology, whose goals include supporting the research, teaching, networking, and mentoring of women in methodology.

Statement of Views: I am honored to be nominated to serve on the APSA Council. If elected, three priorities would guide my efforts on the council: enhancing opportunities for undergraduate students, graduate students, and faculty in under-represented groups that contribute to individual success as well as diversity in the profession; building connections between academic political scientists and the practitioners faced with the challenges of governance, and; fostering integrative approaches to teaching and research that bring together scholars from diverse subfields of political science and across disciplines to provide answers to the complex public policy questions facing society. I look forward to working with APSA staff and fellow council members.

\section{Melanye Price, Prairie View A\&M University}

Melanye Price is Endowed Professor of Political Science at Prairie View A\&M University and principle investigator for their African American Studies Initiative, which is funded the Mellon Foundation. Her research/teaching interests include black politics, public opinion, and political rhetoric. She is the author of two books: The Race Whisperer: Barack Obama and the

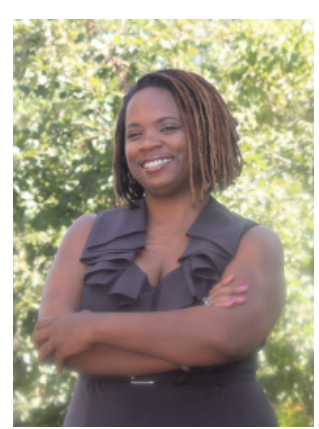

Political Uses of Race (NYU, 2016) and Dreaming Blackness: Black Nationalism and African American Public Opinion (NYU, 2009). $\mathrm{P}$ r i c e completed her BA magna cum laude in geography at Prairie View A\&M University and her MA and $\mathrm{PhD}$ in political science at The Ohio State University. Before returning to Prairie View, she was an associate professor of Africana Studies and Political Science at Rutgers University-New Brunswick. She was the 2017 Black History Month lecturer for US Embassy in Germany. Price provided commentary for the 2016 election season on Philadelphia's NBC 10. She was one of the contributors to Stanley Nelson's documentary, Obama: Through the Fire, which aired on BET. She has also done political commentary for the New York Times, Ms. Magazine, Hartford Courant, Vox, Pacifica and NYC and CT Public Radio.
Statement of Views: APSA provides a space for those interested in the systematic study of politics to create community with like-minded scholars. As a member of the council, I am committed to a professional organization that values rigorous scholarship in all forms and that uses diverse intellectual and methodological frameworks. I will work to make sure that this community is welcoming and inclusive for all of its members, to support efforts that mentor and empower new scholars and create policies and practices that meet the needs of scholars throughout their life span in the profession. 